\title{
Polyphenol Profile, Antioxidant and Hypoglycemic Activity of Acalypha hispida Leaf Extract
}

\author{
H. ALFARISI, S. SA'DIAH AND T. WRESDIYATI* \\ Department of Anatomy, Physiology, and Pharmacology, Faculty of Veterinary Medicine, IPB University (Bogor Agricultural \\ University), Campus Dramaga, Bogor 16680, Indonesia
}

Alfarisi et al.: Antioxidant and Hypoglycemic Activity of Acalypha hispida Leaf Extract

\begin{abstract}
This investigation is aimed at evaluating the polyphenol profile, antioxidant, $\alpha$-glucosidase and $\alpha$-amylase inhibitory and the hypoglycemic activities of Acalypha hispida leaf extract in vivo. Powdered Acalypha hispida leaves were macerated with 70 and $96 \%$ ethanol and decocted in distilled water. The filtrates were evaporated to obtain dry extracts. The extracts were found to have a polyphenol profile (ultraperformance liquid chromatography quadrupole time-of-flight) and to exhibit antioxidant activity (2,2-diphenyl-1-picrylhydrazyl) and $\alpha$-glucosidase and $\alpha$-amylase inhibition (spectrophotometer) in vitro and a hypoglycemic effect in vivo. This study revealed that the number of polyphenol subclasses of the $96 \%$ ethanol extract was greater than that of the other extracts. The 70 and $96 \%$ ethanol and aqueous extracts exhibited strong antioxidant activity $\left(\mathrm{IC}_{50}<10 \mu \mathrm{g} / \mathrm{ml}\right)$. The $96 \%$ ethanol extract showed very high inhibition of $\alpha$-glucosidase and $\alpha$-amylase activities. A hypoglycemic assay of the $96 \%$ ethanol extract at $300 \mathrm{mg} / \mathrm{kg}$ dose exhibited a significant hypoglycemic activity in experimental rats. The present results suggested that the ethanol extract of Acalpha hispida leaves could be an effective hyperglycemic agent acting through inhibiting $\alpha$-glucosidase and $\alpha$-amylase.
\end{abstract}

Key words: Acalypha hispida, hypoglycemia, a-glucosidase, $\alpha$-amylase, polyphenol, oral glucose tolerance test, UPLC-ESI-QTOF

Diabetes mellitus (DM) is a disorder of protein, carbohydrate and fat metabolism. It is characterized by hyperglycemia and reduced insulin secretion or insulin action $^{[1]}$. Long-term hyperglycemia leads to microvascular (retinopathy, cataracts and neuropathy) and macrovascular (stroke and heart failure) complications $^{[2,3]}$. In 2012, there were approximately 422 million people with diabetes worldwide. Moreover, the International Diabetes Federation (IDF) has estimated that by the year 2045, the number of people with diabetes are likely to increase up to 629 million $^{[4]}$. A therapeutic approach to diabetes is to maintain blood glucose levels in the normal range within $2 \mathrm{~h}$ after eating, thereby preventing postprandial hyperglycemia. Postprandial hyperglycemia can be prevented by delaying digestion and absorption of dietary carbohydrates ${ }^{[5]}$. Complex carbohydrates are degraded into disaccharides and oligosaccharides by $\alpha$-amylase in the small intestine. Both of these are further hydrolyzed by $\alpha$-glucosidase into monosaccharides ${ }^{[6]}$. Inhibition of $\alpha$-glucosidase has been proved to reduce postprandial hyperglycemia via

*Address for correspondence

E-mail:utikwr@gmail.com

March-April 2020 inhibition of glucose absorption and suppression of the insulin response ${ }^{[7]}$. Management of near-normal blood glucose levels appears to prevent the progression of diabetic microvascular complications ${ }^{[8]}$.

Recently, bioactive components from plants, have demonstrated potential as alternatives to $\alpha$-glucosidase and $\alpha$-amylase inhibitors. Acalypha hispida (A. hispida) Burm.f. (Euphorbiaceae) is an erect, flowering shrub, used as an ornamental plant in homes and gardens. The plant is also known as a chenille plant or red-hot cat's tail and has medicinal properties. The ethanol extract of $A$. hispida leaves exhibited antimicrobial activity against $P$ seudomonas aeruginosa, Escherichia coli, Staphylococcus aureus and Salmonella typhii ${ }^{[9]}$. Siraj et al. reported that the ethanol extract of $A$. hispida

This is an open access article distributed under the terms of the Creative Commons Attribution-NonCommercial-ShareAlike 3.0 License, which allows others to remix, tweak, and build upon the work non-commercially, as long as the author is credited and the new creations are licensed under the identical terms

Accepted 27 January 2020

Revised 09 January 2020

Received 29 October 2019

Indian J Pharm Sci 2020;82(2):291-299 
leaves showed antiinflammatory and antioxidant activity ${ }^{[9,10]}$. A. hispida leaf extract in phenolic acid was found to be active against Rhizopus sp., Penicillium sp., Sclerotium rolfsii, Fusarium sp., and Aspergillus niger ${ }^{[1]}$. The ethanol and aqueous extracts of $A$. hispida leaves contain a large number of polyphenolic constituents (phenolic acids and flavonoids), including ellagic acid, gallic acid, quercetin, p-coumaric acid, and rutin ${ }^{[10]}$. Particular subclasses of polyphenols demonstrated inhibition of $\alpha$-glucosidase in vitro; these include catechins, flavonoids, flavones, flavonols, isoflavones and phenolic acids. Moreover, some flavonols and phenolic acids inhibit $\alpha$-amylase ${ }^{[12]}$. Polyphenols are powerful antioxidants that effectively scavenge free radicals in the body, inhibiting the development of longterm diabetes complications ${ }^{[13]}$. However, there has been no previous reports on the hypoglycemic activity of $A$. hispida. Therefore, this study aimed to evaluate the polyphenol profile, antioxidant activity, $\alpha$-glucosidase, and $\alpha$-amylase inhibition, and the hypoglycemic effect of $A$. hispida leaf extract in vivo.

\section{MATERIALS AND METHODS}

The A. hispida plants were cultivated in the Tropical Biopharmaca Research Center (TropBRC), IPB University and identified by the Indonesian Institute of Sciences (LIPI). The plants were harvested in the rainy season, January 2018. The materials and reagents used included $\mathrm{D}(+)$-Saccharose (Scharlau Chemie, Spain), 1,1-diphenyl-2-picrylhydrazyl (DPPH; SigmaAldrich, US), $\alpha$-glucosidase from Saccharomyces cerevisiae (Sigma-Aldrich, US), $\alpha$-amylase enzyme from Aspergillus oryzae (Sigma-Aldrich, US), Accu-Check strips, and glucometer (Roche, Germany).

\section{Preparation and extraction:}

A. hispida leaves were dried in the oven for $3 \mathrm{~d}$ at $50^{\circ}$. After drying, the leaves were powdered by grinding and sieved with a size 60 mesh. Extraction was done with distilled water and ethanol (70 and $96 \%$ ). Powdered leaves were added to distilled water at a ratio of 1:10 and heated on a hotplate for $30 \mathrm{~min}$ at $85-90^{\circ}$ with stirring (decoction). Powdered leaves were macerated in 70 or $96 \%$ ethanol at a ratio of 1:10. Maceration was carried out for $72 \mathrm{~h}$ and the filtrates were stirred every $12 \mathrm{~h}$. All three extracts were filtered through a flannel cloth to separate the large particles, and then these were filtered through filter paper to separate fine suspended particles. The filtrates were evaporated to obtain the dry extract.

\section{Phytochemical and polyphenol profile:}

Phytochemicals such as alkaloids, flavonoids, saponins, tannins, quinones, and steroids/triterpenoids in the three extracts were analyzed using the Harborne method ${ }^{[14]}$. The Subclasses of polyphenols such as flavonoids and phenolic acids, were identified using the Najafian and Babji method, with modification and optimization ${ }^{[15,16]}$. The extracts were separated using an Acquity UPLC ${ }^{\circledR}$ HSS C18 column $(1.8 \mu \mathrm{m}, 21 \times 100 \mathrm{~mm}$, Waters, US) with a mass detector $\mathrm{G} 2 \mathrm{Q} / \mathrm{TOF}$ micro mass spectrometer (Waters, USA) and electrospray ionization (ESI) sources at $50^{\circ}$. The samples $(5 \mu \mathrm{l})$ were injected and ran for $23 \mathrm{~min}$ with a flow rate of $0.2 \mathrm{ml} / \mathrm{min}$. The mobile phase consisted of solution $\mathrm{A}$ (water $+5 \mathrm{mM}$ ammonium formic) and solution B (acetonitril $+0.05 \%$ formic acid). The analysis was carried out with a full scan in the mass range of $50-1200 \mathrm{~m} / \mathrm{z}$. Ionization was carried out in the positive electrospray (ESI) mode. The mass spectrometers operated under the following optimized conditions, 4 volt collision energy, 25-50 volts colt ramp, $100^{\circ}$ temperature source, $350^{\circ}$ desolvation temperature and desolvation gas flow of $793 \mathrm{l} / \mathrm{h}$. The data obtained from the UPLC-ESI-QTOF was processed into the Mass-Lynx V.4.1 application. Fragmentary spectra of interest detected were matched with a reference spectra database (MassBank https://massbank.eu/MassBank/; Human Metabolism Database http://www.hmdb.ca// ${ }^{[17]}$.

\section{Antioxidant activity assay:}

The antioxidant activity of the 3 extracts was assessed using the 1,1-diphenyl-2-picrylhydrazyl (DPPH) assay described by Salazar-Aranda et al. ${ }^{[18]}$. Different concentrations of $100 \mu \mathrm{l}$ extracts $(10-1000 \mu \mathrm{g} / \mathrm{ml})$ in ethanol or vitamin $\mathrm{C}$ were dissolved in a $100 \mathrm{ml} \mathrm{DPPH}$ solution and incubated for $30 \mathrm{~min}$ at $37^{\circ}$ under dark. Absorbance was assessed using a microplate reader at $517 \mathrm{~nm}$. Percent inhibition of free radicals was calculated with the formula, $(\mathrm{B}-\mathrm{S}) / \mathrm{B}) \times 100 \%$, where $\mathrm{S}$ is the absorbance of the sample and $\mathrm{B}$ is the absorbance of the blank solution (without samples). The halfmaximal inhibitory concentration $\left(\mathrm{IC}_{50}\right)$ was taken as the ability of the extract to scavenge $50 \%$ DPPH free radicals. The correlation between every concentration and percent inhibition was made to a regression curve. $\mathrm{IC}_{50}$ values were calculated by interpolation.

\section{a-glucosidase inhibition assay:}

$\alpha$-glucosidase inhibition was measured by the Sancheti and Seo method ${ }^{[19]}$. All samples were evaluated in various concentrations of $50-10,000 \mu \mathrm{g} / \mathrm{ml}$. Sample 
dilution $(10 \mu \mathrm{l}), 50 \mu \mathrm{l}$ phosphate buffer $0.1 \mathrm{M}(\mathrm{pH} 7.0)$, $25 \mu 1$ p-nitrophenyl- $\alpha$-D-glucopyranoside (PNP-G) $0.5 \mathrm{mM}$, and $25 \mu 1$ enzyme solution $(0.04 \mathrm{mg} / \mathrm{ml})$ were incubated at $37^{\circ}$ for $30 \mathrm{~min}$. Acarbose was used as a positive control. The reaction was stopped by adding $1 \mathrm{ml}$ of $0.2 \mathrm{M} \mathrm{Na}_{2} \mathrm{CO}_{3}$. The amount of p-nitrophenol produced was measured at $410 \mathrm{~nm}$ using a microplate reader. The percent inhibition and the $\mathrm{IC}_{50}$ value were calculated.

\section{a-amylase inhibition assay:}

The $\alpha$-amylase inhibition was evaluated using the Obuh et al. method ${ }^{[20]}$. All extracts were evaluated at $2000 \mu \mathrm{g} / \mathrm{ml}$. The extract dilution $(200 \mu \mathrm{l})$ and $500 \mu \mathrm{l}$ sodium phosphate buffer $20 \mathrm{mM}(\mathrm{pH} 6.9$ with $6 \mathrm{mM}$ $\mathrm{NaCl})$ containing $\alpha$-amylase enzyme $(0.5 \mathrm{mg} / \mathrm{ml})$ were incubated for $10 \mathrm{~min}$ at $25^{\circ}$. The $1 \%$ starch solution $(500 \mu \mathrm{l})$ in $20 \mathrm{mM}$ sodium phosphate buffer was added into the mixture. The mixture was incubated for $10 \mathrm{~min}$ at $25^{\circ}$. The reaction was stopped by adding $1 \mathrm{ml}$ dinitrosalicylic acid (DNS) and then incubated in boiling water for $5 \mathrm{~min}$. The absorbance was measured at $540 \mathrm{~nm}$ using a spectrophotometer ${ }^{[21]}$. The percent inhibition was calculated.

\section{Hypoglycemic effect test in vivo:}

All animal procedures were approved by the Animal Ethics Committee, Faculty of Veterinary Medicine, IPB University (approval number: 143/KEH/SKE/ $\mathrm{VI} / 2019$ ). A total of 28 male Sprague-Dawley (SD) rats (200-250 g; 8-12 d) were used in this study. Acclimatization was carried out for $7 \mathrm{~d}$. Rat cages were housed at $22-25^{\circ}$, humidity $55-63 \%$, and $12 \mathrm{~h}$ bright light and $12 \mathrm{~h}$ darkness. The experimental animals were given standard protein feed and water ad libitum.

The oral glucose tolerance test (OGTT) used was as described by Wresdiyati et al. ${ }^{[22]}$. The extract that exhibited the highest inhibition of $\alpha$-glucosidase was used for the OGTT. Rats were divided into groups $(\mathrm{n}=4)$, negative control (NC), positive control (PC), and five groups of various extracts at doses 100 (D1), 200 (D2), 300 (D3) and $400 \mathrm{mg} / \mathrm{kg}$ (D4), and acarbose (AR) $4.5 \mathrm{mg} / \mathrm{kg}$ for comparison. All rats were fasted for $10 \mathrm{~h}$ and blood glucose levels were measured at $0 \mathrm{~min}$ as a baseline. The PC and $\mathrm{NC}$ groups were given water. The extracts and AR groups were orally administered according to the dosage. After $10 \mathrm{~min}$, each group was administered $1 \mathrm{~m}$ of $90 \%$ sucrose orally, except for the $\mathrm{NC}$ group that was given water as a placebo. Blood sugar levels were measured at 30,60,90, and $120 \mathrm{~min}$ using the Accu-Chek strip (Roche, Germany).

\section{Statistical analysis:}

The phytochemicals and polyphenol profiles were qualitatively described. The antioxidant activity, inhibition of $\alpha$-glucosidase, and blood glucose levels were analyzed using one-way ANOVA. If the treatment had an effect, it was followed by Duncan's Multiple Range Test (DMRT). The analysis used the statistical application of SPSS 22.00.

\section{RESULTS AND DISCUSSION}

The characteristics of $A$. hispida leaf extract are displayed in Table 1 . The yields of the extracts in aqueous, 70, and $96 \%$ ethanol were 26.35, 17.24 and $17.43 \%$, respectively. The extracts were obtained as dry extracts with specific odors. Each extract exhibited a different taste and color. In the present study, the phytochemical assay of ethanol and aqueous $A$. hispida leaf extracts showed the presence of flavonoids, tannins, saponins and steroids. All of these metabolites were detected in the 70 and $96 \%$ ethanol extracts and saponin was absent in the aqueous extract. Previous studies reported the presence of glycosides, flavonoids, steroids, phlobatin, saponin and hyroxylanetquinone from methanol and aqueous extracts of $A$. hispida leaves from Nigeria and Bangladesh ${ }^{[23,24]}$. The phytochemical screening of the hexane extract of $A$. hispida leaves revealed alkaloids, flavonoids and phenolic compounds ${ }^{[25]}$. The different bioactive compounds of A. hispida are probably due to the different geographical origin of the plants $^{[22]}$. Polyphenol profiles were further identified based on ion mass using the UPLC-ESI-QTOF. The results of the analysis are shown in chromatograms at low energy (4 volts, fig. 1). Polyphenols have two general classes, flavonoids and phenolic acids ${ }^{[26]}$. Both of these are shown in Table 2. The polyphenol contents of the $96 \%$ ethanol extract were chalcones (phloretin, phloridzin), flavonols $((+)$-epicatechin, kaempferol, myricetin, quercetin, rutin), flavanones (naringin, naringenin, eriodictyol), flavones (apigenin, tangeretin, rhoifolin) and isoflavonoids (daidzein, daidzin, genistin, biochanin A). The polyphenol contents of the $70 \%$ ethanol extract were chalcones (phloridzin), flavonols ((-)-epicatechin, kaempferol, myricetin, quercetin, rutin), flavanones (naringin, naringenin, eriodictyol), and isoflavonoids (daidzin, dan biochanin A). In addition, the polyphenol contents of the aqueous extract were flavonols (kaempferol, quercetin, rutin), 
TABLE 1: CHARACTERISTICS OF A. HISPIDA LEAF EXTRACT

\begin{tabular}{|c|c|c|c|c|}
\hline \multicolumn{2}{|l|}{ Parameter } & $96 \%$ ethanol extract & $70 \%$ ethanol extract & Aqueous extract \\
\hline \multicolumn{2}{|l|}{ Yield (\%) } & 17.43 & 17.24 & 26.35 \\
\hline \multicolumn{5}{|l|}{ Organoleptic: } \\
\hline \multicolumn{2}{|l|}{ Form } & Powder & Powder & Powder \\
\hline \multicolumn{2}{|l|}{ Odor } & Specific & Specific & Specific \\
\hline \multicolumn{2}{|l|}{ Taste } & Bitter & Bitter acidity & Saltiness acidity \\
\hline \multicolumn{2}{|l|}{ Color } & Dark green & Brown & Dark brown \\
\hline \multicolumn{5}{|l|}{ Phytochemicals: } \\
\hline \multirow[t]{3}{*}{ Alkaloids: } & Wagner & - & - & - \\
\hline & Mayer & - & - & - \\
\hline & Dragendorf & - & - & - \\
\hline \multicolumn{2}{|l|}{ Flavonoids } & + & + & + \\
\hline \multicolumn{2}{|l|}{ Tanins } & + & + & + \\
\hline \multicolumn{2}{|l|}{ Saponins } & + & + & - \\
\hline \multicolumn{2}{|l|}{ Quionones } & - & - & - \\
\hline \multicolumn{2}{|l|}{ Steroids } & + & + & + \\
\hline \multicolumn{2}{|c|}{ Triterpenoids } & - & - & - \\
\hline
\end{tabular}
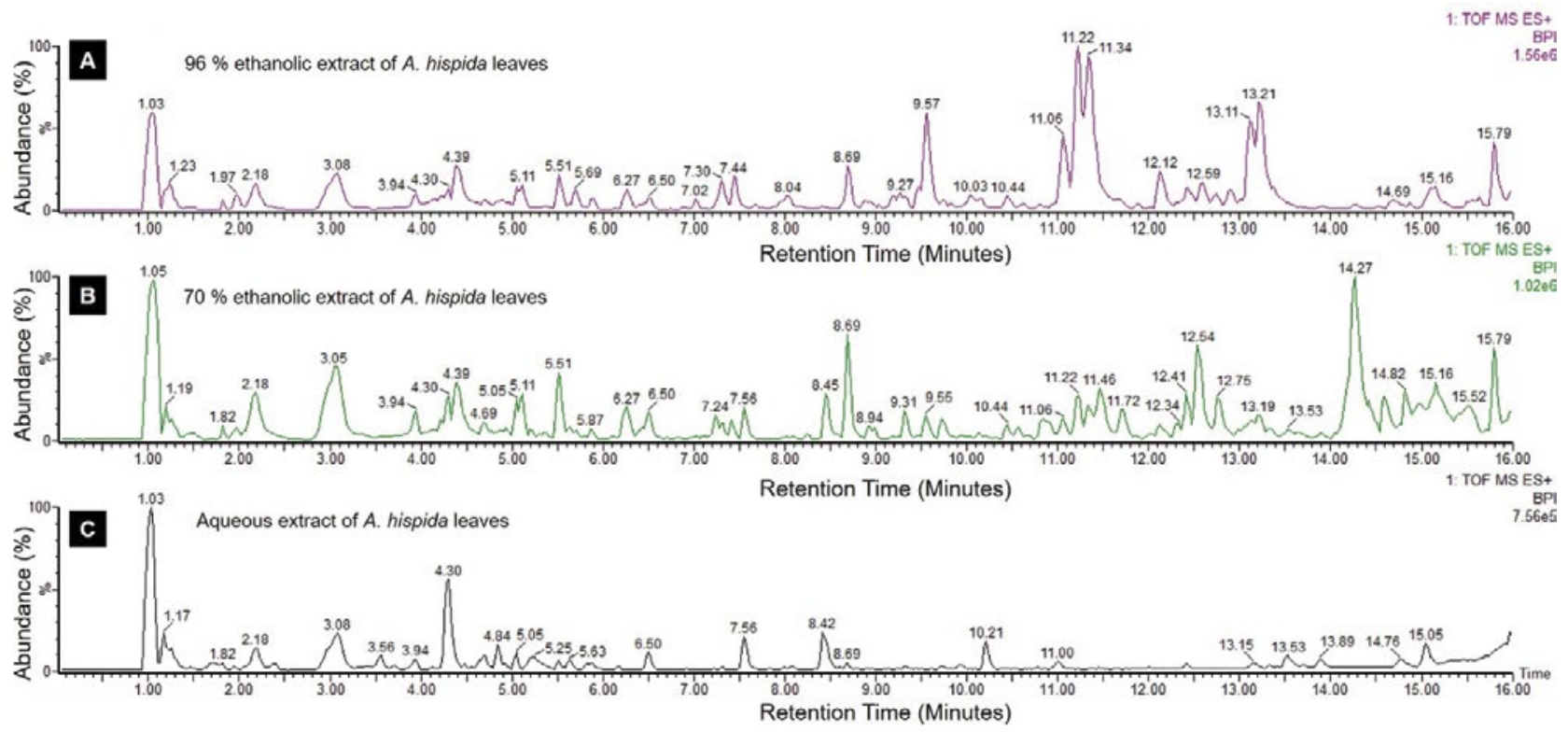

Fig. 1: Chromatograms of $\boldsymbol{A}$. hispida leaf extracts

Chromatograms in base peak intensity (BPI) mode of $A$. hispida leaf extract at low energy (4 volt) with positive electrospray ionization, A. $96 \%$ ethanol extract, B. $70 \%$ ethanol extract, and C. aqueous extract

flavanones (naringin) and isoflavonoids (daidzein, daidzin, dan biochanin A).

All the A. hispida leaf extracts were found to contain phenolic acids belonging to the hydroxybenzoic acid and hydroxycinnamic acid groups (Table 3). The polyphenol content of the 70 and $96 \%$ ethanol extracts were hydroxybenzoic acids (ellagic acid, gallic acid, syringic acid) and hydroxycinnamic acids (rosmarinic acid, sinapic acid, chicoric acid). The aqueous extract showed the presence of hydroxybenzoic acids (ellagic acid, gallic acid, galloyl glucose) and hydroxycinnamic acids (rosmarinic acid, sinapic acid, chicoric acid). The present results revealed that the number of polyphenols in the $96 \%$ ethanol extract of $A$. hispida leaves was greater than that of the other extracts. It has been reported by Siraj et al. that some of the polyphenols in the ethanol and aqueous $A$. hispida leaf extracts were ellagic acid, gallic acid, quercetin, p-coumaric acid and rutin $^{[10]}$.

The results of the DPPH antioxidant assay are shown in Table 4. The $\mathrm{IC}_{50}$ values of the ethanol (70 and $96 \%$ ) and aqueous extracts of $A$. hispida leaves were 


\begin{tabular}{|c|c|c|c|c|c|}
\hline \multirow{2}{*}{ Compound identification } & \multirow{2}{*}{ Formula } & \multirow{2}{*}{$\mathrm{m} / \mathrm{z}$ calculated } & \multicolumn{3}{|c|}{ Retention time $(\mathrm{min})$} \\
\hline & & & Aqueous extract & $70 \%$ ethanol extract & $96 \%$ ethanol extract \\
\hline \multicolumn{6}{|l|}{ Chalcones } \\
\hline Phloretin & $\mathrm{C}_{15} \mathrm{H}_{14} \mathrm{O}_{5}$ & 275.0919 & - & - & 8.36 \\
\hline Phloridzin & $\mathrm{C}_{21} \mathrm{H}_{24} \mathrm{O}_{10}$ & 437.1448 & - & 6.34 & 5.73 \\
\hline \multicolumn{6}{|l|}{ Flavonols } \\
\hline$(+)$-Epicatechin & $\mathrm{C}_{15} \mathrm{H}_{14} \mathrm{O}_{6}$ & 291.0869 & - & - & 6.61 \\
\hline (-)-Epicatechin & $\mathrm{C}_{15} \mathrm{H}_{14} \mathrm{O}_{6}$ & 291.0869 & - & 1.33 & - \\
\hline Kaempferol & $\mathrm{C}_{15} \mathrm{H}_{10} \mathrm{O}_{6}$ & 287.0556 & 8.45 & 5.51 & 5.53 \\
\hline Myricetin & $\mathrm{C1}_{5} \mathrm{H}_{10} \mathrm{O}_{8}$ & 319.0454 & - & 6.21 & 6.27 \\
\hline Quercetin & $\mathrm{C}_{15} \mathrm{H}_{10} \mathrm{O}_{7}$ & 303.0505 & 7.52 & 5.29 & 5.07 \\
\hline Rutin & $\mathrm{C}_{27} \mathrm{H}_{30} \mathrm{O}_{16}$ & 611.1612 & 5.05 & 5.02 & 5.02 \\
\hline \multicolumn{6}{|l|}{ Flavanones } \\
\hline Naringin & $\mathrm{C}_{27} \mathrm{H}_{32} \mathrm{O}_{14}$ & 581.187 & 5.66 & 5.91 & 9.83 \\
\hline Naringenin & $\mathrm{C}_{15} \mathrm{H}_{12} \mathrm{O}_{5}$ & 273.0763 & - & 6.17 & 7.94 \\
\hline Eriodictyol & $\mathrm{C}_{15} \mathrm{H}_{12} \mathrm{O}_{6}$ & 289.0712 & - & 4.30 & 4.37 \\
\hline \multicolumn{6}{|l|}{ Flavones } \\
\hline Apigenin & $\mathrm{C}_{15} \mathrm{H}_{10} \mathrm{O}_{5}$ & 271.0606 & - & - & 8.34 \\
\hline Tangeretin & $\mathrm{C}_{20} \mathrm{H}_{20} \mathrm{O}_{7}$ & 373.1287 & - & - & 7.34 \\
\hline $\begin{array}{l}\text { Rhoifolin } \\
\text { Isoflavonoid }\end{array}$ & $\mathrm{C}_{27} \mathrm{H}_{30} \mathrm{O}_{14}$ & 579.1714 & - & - & 5.15 \\
\hline Daidzein & $\mathrm{C}_{15} \mathrm{H}_{10} \mathrm{O}_{4}$ & 255.0657 & 8.38 & - & 1.36 \\
\hline Daidzin & $\mathrm{C}_{21} \mathrm{H}_{20} \mathrm{O}_{9}$ & 417.1186 & 6.21 & 3.72 & 2.65 \\
\hline Genistin & $\mathrm{C}_{21} \mathrm{H}_{20} \mathrm{O}_{10}$ & 433.1135 & - & - & 10.35 \\
\hline Biochanin A & $\mathrm{C}_{16} \mathrm{H}_{12} \mathrm{O}_{5}$ & 285.0763 & 10.19 & 5.58 & 10.24 \\
\hline
\end{tabular}

TABLE 3: THE PHENOLIC ACID CONTENT OF A. HISPIDA LEAF EXTRACT

\begin{tabular}{|c|c|c|c|c|c|}
\hline \multirow{2}{*}{$\begin{array}{l}\text { Compound } \\
\text { identification }\end{array}$} & \multirow{2}{*}{ Formula } & \multirow{2}{*}{$\mathrm{m} / \mathrm{z}$ calculated } & \multicolumn{3}{|c|}{ Retention time (min) } \\
\hline & & & Aqueous extract & $70 \%$ ethanol extract & $96 \%$ ethanol extract \\
\hline \multicolumn{6}{|c|}{ Hydroxybenzoic acids } \\
\hline Ellagic acid & $\mathrm{C}_{14} \mathrm{H}_{6} \mathrm{O}_{8}$ & 303.0141 & 4.57 & 5.29 & 4.57 \\
\hline Gallic acid & $\mathrm{C}_{7} \mathrm{H}_{6} \mathrm{O}_{5}$ & 171.0293 & 1.93 & 4.60 & 1.93 \\
\hline Galloyl glucose & $\mathrm{C}_{13} \mathrm{H}_{16} \mathrm{O}_{10}$ & 333.0822 & 1.29 & - & - \\
\hline Syringic acid & $\mathrm{C}_{9} \mathrm{H}_{10} \mathrm{O}_{5}$ & 199.0606 & - & 5.45 & 3.74 \\
\hline \multicolumn{6}{|c|}{ Hydroxycinnamic acids } \\
\hline Rosmarinic acid & $\mathrm{C}_{18} \mathrm{H}_{16} \mathrm{O}_{8}$ & 361.0923 & 5.07 & 4.28 & 8.47 \\
\hline Sinapic acid & $\mathrm{C}_{11} \mathrm{H}_{12} \mathrm{O}_{5}$ & 225.0763 & 5.73 & 7.01 & 6.99 \\
\hline Chicoric acid & $\mathrm{C}_{22} \mathrm{H}_{18} \mathrm{O}_{12}$ & 475.0877 & 6.05 & 4.77 & 1.67 \\
\hline
\end{tabular}

TABLE 4: THE ANTIOXIDANT ACTIVITY (IC50 VALUES) OF A. HISPIDA LEAF EXTRACT

\begin{tabular}{lc}
\hline Sample & $\mathrm{IC}_{50}$ value $(\mu \mathrm{g} / \mathrm{ml})$ \\
\hline $96 \%$ ethanol extract & $<10$ \\
$70 \%$ ethanol extract & $<10$ \\
Aqueous extract & $<10$ \\
Vitamin C & 4.33
\end{tabular}

Each value is mean $\pm S D(n=3)$. The different superscript $\left({ }^{a-c}\right)$ in the raw represents a significantly different result $p<0.05$. n.d, not detected

$<10 \mu \mathrm{g} / \mathrm{ml}$, while the $\mathrm{IC}_{50}$ value of the vitamin $\mathrm{C}$ was $4.33 \mu \mathrm{g} / \mathrm{ml}$. Based on a previous study, the antioxidant $\mathrm{IC}_{50}$ value of $<10 \mu \mathrm{g} / \mathrm{ml}$ could be regarded as highly active ${ }^{[27]}$. The strong antioxidant activity of the extract may be correlated with the presence of the flavonoid compounds, such as kaempferol, quercetin, and rutin ${ }^{[28]}$; it may also be attributed to the presence of gallic acid and rosmarinic acid in the extracts ${ }^{[29,30]}$. The $\mathrm{IC}_{50}$ value $(<10 \mu \mathrm{g} / \mathrm{ml})$ of the ethanol and aqueous extracts in the present study was lower than that of the $\mathrm{IC}_{50}$ value of the ethanol $(14 \mu \mathrm{g} / \mathrm{ml})$ and aqueous $(17 \mu \mathrm{g} / \mathrm{ml})$ extracts reported in a previous study ${ }^{[31]}$. These results indicated that ethanol and aqueous extracts of $A$. hispida leaves from Indonesia exhibited stronger antioxidant activity compared to that of the extracts of $A$. hispida leaves 
from Bangladesh. Carbohydrate-hydrolyzing enzyme activity was evaluated via $\alpha$-glucosidase and $\alpha$-amylase inhibition. The levels of inhibition of the $A$. hispida leaf extracts on $\alpha$-glucosidase are shown in Table 5. The $\mathrm{IC}_{50}$ value of the $96 \%$ ethanol extract $(785 \pm 21 \mu \mathrm{g} / \mathrm{ml})$ was lower than that of the $70 \%$ ethanol extract (3244 \pm $22 \mu \mathrm{g} / \mathrm{ml})$. The $\mathrm{IC}_{50}$ value of the aqueous extract was not reported probably that the aqueous extract might have had no inhibitory effect on $\alpha$-glucosidase. However, the $\mathrm{IC}_{50}$ value of acarbose was lower than that of the $96 \%$ ethanol extract.

All $A$. hispida leaf extracts inhibited $\alpha$-amylase activity at $2000 \mu \mathrm{g} / \mathrm{ml}$ (Table 6). The highest inhibitory effect was shown by the $96 \%$ ethanol extract $(44.15 \%)$, followed by the $70 \%$ ethanol extract $(37.70 \%)$ at $2000 \mu \mathrm{g} / \mathrm{ml}$. The aqueous extract showed low inhibitory effect $(35.08 \%)$ at $2000 \mu \mathrm{g} / \mathrm{ml}$. The best $\alpha$-glucosidase and $\alpha$-amylase inhibitory activity was demonstrated by the $96 \%$ ethanol extract of $A$. hispida leaves; this could be owing to the fact that greater number of polyphenol constituents were present in this extract with strong antioxidant activity. Therefore, the $96 \%$ ethanol A. hispida leaf extract was used to study the hypoglycemic effect in vivo. The $96 \%$ ethanol extract exhibited greater inhibition of $\alpha$-glucosidase and $\alpha$-amylase activity than other extracts (Tables 3 and 4 ). This $\alpha$-glucosidase and $\alpha$-amylase inhibitory effect could be related to the presence of higher flavonoid contents in the extract (Table 2). The absence of flavones (apigenin, tangeretin, rhoifolin) and chalcones (phloretin) did not significantly affect antioxidant activity (Table 4), but significantly reduced the inhibitory activity of the extract on $\alpha$-glucosidase and $\alpha$-amylase enzymes (Tables 5 and 6). Apigenin and phloretin were reported to reversibly inhibit $\alpha$-glucosidase activity ${ }^{[31,32]}$. Tangeretin and rhoifolin were found to inhibit $\alpha$-glucosidase and $\alpha$-amylase activity ${ }^{[33]}$. The OGTT test was conducted to evaluate the hypoglycemic potential of these extracts. The blood glucose profile after an oral glucose challenge to all groups of rats is shown in fig. 2. At $0 \mathrm{~min}$, the blood glucose levels of all groups were in the normal range $(80-110 \mathrm{mg} / \mathrm{dl})$. The NC group showed constant blood glucose at 0, 30, 60 and $120 \mathrm{~min}$. The PC group,

TABLE 5: IC50 VALUE OF A. HISPIDA LEAF EXTRACT FOR $\alpha$-GLUCOSIDASE

\begin{tabular}{lc}
\hline Sample & $\mathrm{IC}_{50}$ value $(\mu \mathrm{g} / \mathrm{ml})$ \\
\hline $96 \%$ ethanolic extract & $785 \pm 210^{\mathrm{b}}$ \\
$70 \%$ ethanolic extract & $3244 \pm 220^{\mathrm{c}}$ \\
Aqueous extract & $\mathrm{n} . \mathrm{d}$ \\
Acarbose & $0.27 \pm 0.01^{\mathrm{a}}$ \\
\hline
\end{tabular}

TABLE 6: INHIBITION OF A. HISPIDA LEAF EXTRACT FOR $\alpha$-AMYLASE AT $2000 \mathrm{MG} / \mathrm{ML}$

\begin{tabular}{cc}
\hline Sample & Inhibition (\%) \\
\hline $96 \%$ ethanol extract & 44.15 \\
$70 \%$ ethanol extract & 37.70 \\
Aqueous extract & 35.08 \\
\hline
\end{tabular}

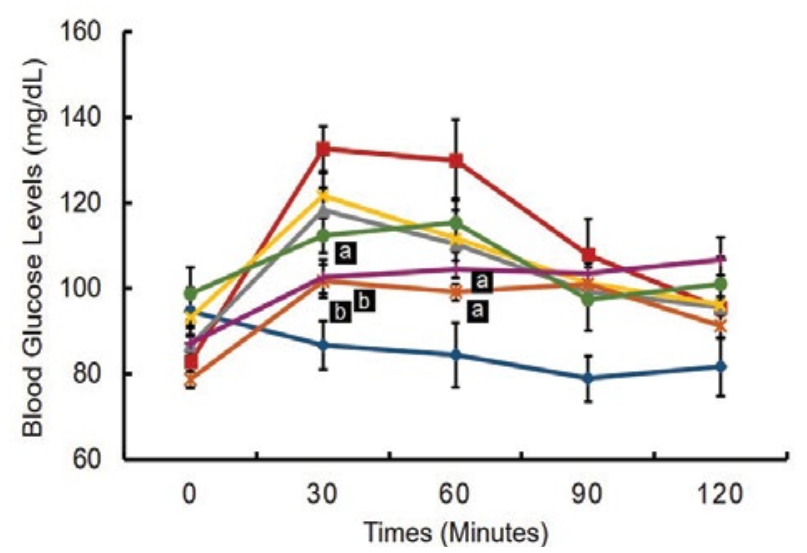

Fig. 2: Blood glucose profile of $A$. hispida leaf ethanol extract-treated rats subjected to OGTT

(一०- ) Negative control, (-口-) positive control, $A$. hispida leaf ethanol extract $\left(-{ }_{-}-\right) 100 \mathrm{mg} / \mathrm{kg},(-\times-)$ $200 \mathrm{mg} / \mathrm{kg}$, (-× $-300 \mathrm{mg} / \mathrm{kg},(-\bullet-) 400 \mathrm{mg} / \mathrm{kg}$ and (一|-) acarbose $4.5 \mathrm{mg} / \mathrm{kg}$

which was given $90 \%$ sucrose without any treatment, exhibited a rapid increase in blood glucose level $(132 \mathrm{mg} / \mathrm{dl})$ after $30 \mathrm{~min}$ following sucrose treatment. Subsequently, blood glucose levels of the PC group decreased at 120 min reaching the normal range. The administration of $A$. hispida leaf extract at doses of 100 and $200 \mathrm{mg} / \mathrm{kg}$ did not significantly decrease blood glucose levels at 30 and $60 \mathrm{~min}$. The extract at a dose of $300 \mathrm{mg} / \mathrm{kg}$ and $4.5 \mathrm{mg} / \mathrm{kg}$ acarbose significantly reduced blood glucose levels at 30 and $60 \mathrm{~min}$, while the extract at $400 \mathrm{mg} / \mathrm{kg}$ significantly decreased blood glucose levels only at $30 \mathrm{~min}$ but not at $60 \mathrm{~min}$. At $90 \mathrm{~min}$, blood glucose levels of all the treatment groups (except the negative controls) were not significantly different. Finally, all groups returned to normal blood glucose levels at $120 \mathrm{~min}$. The area under the curve (AUC) during the OGTT was calculated to determine the total hypoglycemic response after administration of A. hispida leaf extract followed by sucrose (fig. 3). All A. hispida leaf extract treated groups at doses of 100 , 200,300 and $400 \mathrm{mg} / \mathrm{kg}$, exhibited similar AUC as that of the acarbose group. The group that received extract at a dose of $300 \mathrm{mg} / \mathrm{kg}$ and the acarbose-treated group showed significantly lower AUC $(p<0.05)$ than that of the PC group. The groups that received extract at a dose of $300 \mathrm{mg} / \mathrm{kg}$ demonstrated significant hypoglycemic activity compared to the groups treated with other doses 


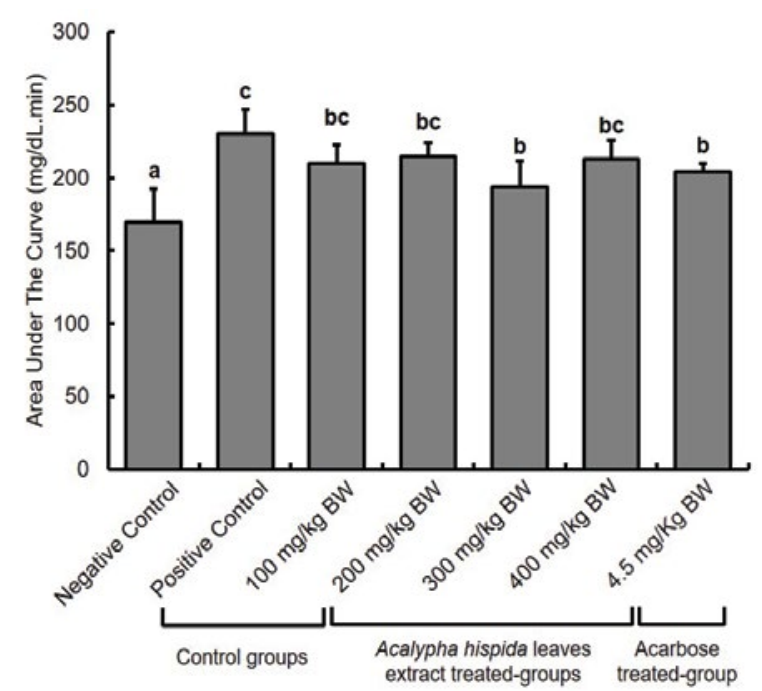

Fig. 3: Area under the curve of postprandial blood glucose levels of rats treated with $96 \%$ ethanol extract of A. hispida leaves

Rats were treated with $100,200,300$ and $400 \mathrm{mg} / \mathrm{kg}$ of $96 \%$ ethanol extract of $A$. hispida leaf and acarbose had decreased AUC, but only the $300 \mathrm{mg} / \mathrm{kg}$ dose and acarbose groups showed significant reduction in AUC. Values are mean \pm standard deviation $(n=4)$. The different superscript $\left({ }^{\mathrm{a}-\mathrm{c}}\right)$ represents significantly different $p<0.05$ by DMRT

of the extract. The hypoglycemic effect was shown after the administration of an extract followed by sucrose. Both the groups given $300 \mathrm{mg} / \mathrm{kg}$ of extract and the group given $4.5 \mathrm{mg} / \mathrm{kg}$ acarbose exhibited significantly reduced postprandial blood glucose levels compared to those of PC group. These reduced postprandial blood glucose levels reflected in a lower AUC (fig. 3). Since the $\mathrm{IC}_{50}$ value of $\alpha$-glucosidase inhibitory activity of the acarbose group $(0.27 \pm 0.01 \mu \mathrm{g} / \mathrm{m})$ was lower than that of the $96 \%$ ethanol extract of $A$. hispida leaf group $(785 \pm 210 \mu \mathrm{g} / \mathrm{ml})$, the $96 \%$ ethanolic extract of $A$. hispida leaf could have a different mechanism of reducing postprandial blood glucose levels. An additional mechanism is the binding to the active site of glucose transporter-2 (GLUT2) and sodium-dependent glucose transporter-1 (SGLT1) ${ }^{[6,34]}$. GLUT2 and SGLT1 mediate glucose intake into the small intestine ${ }^{[35]}$. SGLT1 plays an essential role in glucose absorption, especially before meals ${ }^{[6]}$. After eating, carbohydrates are hydrolyzed by $\alpha$-glucosidase and $\alpha$-amylase to create conditions of high luminal glucose concentration $(50-500 \mathrm{mM})$. This condition stimulates GLUT2 translocation from intracellular vesicles to the apical membrane. GLUT2 then becomes the main pathway for glucose absorption ${ }^{[36,37]}$. Phloridzin is known as a specific inhibitor of SGLT1, and phloretin is known as a specific GLUT2 inhibitor ${ }^{[37]}$. Binding of the active site of SGLT1 and GLUT2 can inhibit glucose intake in the small intestine. Long-term hyperglycemia during diabetes induces a high risk of microvascular and macrovascular complications ${ }^{[3]}$. Hyperglycemia stimulates development and progression of diabetes through specific inhibition of different mechanisms such as, increased polyol pathway flux, increased advanced glycation end-product formation, activation of protein kinase $\mathrm{C}$ (PKC), increased hexosamine pathway flux and a decrease in antioxidant defenses ${ }^{[38,39]}$. All these mechanisms cause accumulation of reactive oxygen species (ROS) ${ }^{[39]}$. The imbalance of radical-generating ROS and radical-scavenging systems leads to oxidative stress, which might trigger the pathogenesis of diabetes, such as oxygen free radical scavenging, glucose autooxidation, nonenzymatic protein glycosylation, lipid peroxide formation and alteration in the antioxidant systems $^{[40]}$. ROS in diabetes might also react with lipids, generating lipid abnormalities, such as elevated low-density lipoprotein (LDL) and cholesterol. These abnormalities might be worsened with the formation of oxysterols (formed from the oxidation of cholesterol), glycated LDL, and oxidized LDLs ${ }^{[41]}$.

Most reactive ROS, which plays an essential role in diabetes complications, is superoxide $\left(\mathrm{O}_{2}^{-}\right)^{[41]}$. Superoxide is converted by superoxide dismutase (SOD) to hydrogen peroxide $\left(\mathrm{H}_{2} \mathrm{O}_{2}\right)^{[42]} \cdot \mathrm{H}_{2} \mathrm{O}_{2}$ is catalyzed to oxygen $\left(\mathrm{O}_{2}\right)$ and water $\left(\mathrm{H}_{2} \mathrm{O}\right)$ by glutathione peroxidases (GPX) and catalase (Cat) ${ }^{[43]}$. The limitation of endogenous SOD in the cells to scavenge superoxide causes conditions of oxidative stress. Oxidative stress is likely to contribute to the major mechanism failure of insulin secretion and insulin action ${ }^{[44,45]}$. The administration of natural products, like Swietenia mahagoni seed, with strong antioxidant activity, was proved to maintain the antioxidant content of $\mathrm{Cu}, \mathrm{Zn}$ SOD and to stimulate insulin secretion in the pancreas of diabetic rat models ${ }^{[46]}$. The $96 \%$ ethanol extract of $A$. hispida, which demonstrated strong antioxidant activity, might have great potential as a superoxide scavenger to prevent oxidative stress conditions and to inhibit diabetic complications.

In summary, the $96 \%$ ethanol extract of $A$. hispida leaves showed the highest number of polyphenol subclasses and strong antioxidant activity. This extract also exhibited the highest inhibitory activity to $\alpha$-glucosidase and $\alpha$-amylase; it also demonstrated hypoglycemic activity in rats. Therefore, the $96 \%$ ethanol extract of $A$. hispida leaves has great potential as a hypoglycemic agent through inhibition of $\alpha$-glucosidase and $\alpha$-amylase activity. 


\section{Acknowledgments:}

The authors thank the Directorate of Research and Community Service, General Directorate of Strengthening for Research and Development, Ministry of Research, Technology, and Higher Education of the Republic of Indonesia in fundng research through PMDSU research grant scheme year 2019 (Number: 261/SP2H/LT/DRPM/2019).

\section{REFERENCES}

1. Aouacheri O, Saka S, Krim M, Messaadia A, Maidi I. The investigation of the oxidative stress-related parameters in type 2 diabetes mellitus. Can J Diabetes 2015;39(1):44-9.

2. Bahtiyar G, Gutterman D, Lebovitz H. Heart failure: a major cardiovascular complication of diabetes mellitus. Curr Diab Rep 2016;16(11):116.

3. Asmat U, Abad K, Ismail K. Diabetes mellitus and oxidative stress-a concise review. Saudi Pharm J 2016;24(5):547-53.

4. International Diabetes Federation. IDF diabetes atlas $8^{\text {th }}$ edition. International Diabetes Federation 2017.

5. Singh R, Rand JS, Coradini M, Morton JM. Effect of acarbose on postprandial blood glucose concentrations in healthy cats fed low and high carbohydrate diets. J Feline Med Surg 2015;17(10):848-57.

6. Satoh T, Igarashi M, Yamada S, Takahashi N, Watanabe K. Inhibitory effect of black tea and its combination with acarbose on small intestinal $\alpha$-glucosidase activity. J Ethnopharmacol 2015;161:147-55.

7. Serra-Barcellona C, Habib NC, Honore SM, Sánchez SS, Genta SB. Enhydrin regulates postprandial hyperglycemia in diabetic rats by inhibition of $\alpha$-glucosidase activity. Plant Foods Hum Nutr 2017;72(2):156-60.

8. Nathan DM, Buse JB, Davidson MB, Ferrannini E, Holman RR, Sherwin R, et al. Medical management of hyperglycemia in type 2 diabetes: a consensus algorithm for the initiation and adjustment of therapy: a consensus statement of the American Diabetes Association and the European Association for the Study of Diabetes. Diabetes care 2009;32(1):193-203.

9. Bokshi B, Sayeed MA, Ahmed MI, Karmakar UK, Sadhu SK. Assessment of antimicrobial and cytotoxic activities of ethanolic extract of leaves of Acalypha hispida. Int J Pharm Sci Res 2012;3(6):1705-8.

10. Siraj MA, Shilpi JA, Hossain MG, Uddin SJ, Islam MK, Jahan IA, et al. Anti-inflammatory and antioxidant activity of Acalypha hispida leaf and analysis of its major bioactive polyphenols by HPLC. Adv Pharm Bull 2016;6(2):275-83.

11. Ejechi BO, Souzey JA. Inhibition of biodeterioration of yam tuber Dioscorea rotundata Poir in storage with phenolic extract of Acalypha hispida Burm. f. leaves. J Stored Prod Res 1999;35(2):127-34.

12. Dal S, Sigrist S. The protective effect of antioxidants consumption on diabetes and vascular complications. Diseases 2016;4(3):24.

13. Bhattacharya S, Sil PC. Role of plant-derived polyphenols in reducing oxidative stress-mediated diabetic complications. React Oxyg Species 2018;5(13):15-34.

14. Harborne AJ. Phytochemical methods a guide to modern techniques of plant analysis. $3^{\text {rd }}$ edn. Berlin. Springer Science \& Business Media 1998.
15. Panche AN, Diwan AD, Chandra SR. Flavonoids: an overview. J Nutr Sci 2016;5(47):1-15.

16. Najafian L, Babji AS. Production of bioactive peptides using enzymatic hydrolysis and identification antioxidative peptides from patin (Pangasius sutchi) sarcoplasmic protein hydolysate. J Funct Foods 2014;9:280-9.

17. Gil-Solsona R, Calduch-Giner JA, Nácher-Mestre J, LacalleBergeron L, Sancho JV, Hernández F, et al. Contributions of MS metabolomics to gilthead sea bream (Sparus aurata) nutrition. Serum fingerprinting of fish fed low fish meal and fish oil diets. Aquaculture 2019;498:503-12.

18. Salazar-Aranda R, Pérez-Lopez LA, Lopez-Arroyo J, Alanís-Garza BA, Waksman de Torres N. Antimicrobial and antioxidant activities of plants from northeast of Mexico. Evid Based Complement Alternat Med 2011;2011:1-6.

19. Sancheti S, Seo S. Chaenomeles sinensis: a potent $\alpha$-and $\beta$-glucosidase inhibitor. Am J Pharmacol Toxicol 2009;4(1):811.

20. Oboh G, Olabiyi AA, Akinyemi AJ, Ademiluyi AO. Inhibition of key enzymes linked to type 2 diabetes and sodium nitroprusside-induced lipid peroxidation in rat pancreas by water-extractable phytochemicals from unripe pawpaw fruit (Carica papaya). J Basic Clin Physiol Pharmacol 2014;25(1):21-34.

21. Worthington Biochemicals Corporation. Worthington enzyme manual; 2019.

22. Wresdiyati T, Sa'diah S, Winarto A, Febriyani V. Alphaglucosidase inhibition and hypoglycemic activities of Swietenia mahagoni seed extract. Hayati 2015;22(2):73-8.

23. Iniaghe OM, Malomo SO, Adebayo JO. Proximate composition and phytochemical constituents of leaves of some Acalypha species. Pak J Nutr 2009;8(3):256-8.

24. Okorondu S, Sokari T, Okorondu M, Chinakwe E. Phytochemical and antibacterial properties of Acalypha hispida leaves. Int J Nat Applied Sci 2009;5(2):38-45.

25. Onocha PA, Oloyede GK, Afolabi QO. Chemical composition, cytotoxicity and antioxidant activity of essential oils of Acalypha hispida flowers. Inter J Pharm 2011;7(1):144-8.

26. Abbas M, Saeed F, Anjum FM, Afzaal M, Tufail T, Bashir MS, Ishtiaq A, Hussain S, Suleria HA. Natural polyphenols: An overview. Int J Food Prop 2017;20(8):1689-99.

27. Phongpaichit S, Nikom J, Rungjindamai N, Sakayaroj J, Hutadilok-Towatana N, Rukachaisirikul V, et al. Biological activities of extracts from endophytic fungi isolated from Garcinia plants. FEMS Immunol Med Microbiol 2007;51(3):517-25.

28. Zheng CD, Li G, Li HQ, Xu XJ, Gao JM, Zhang AL. DPPH-scavenging activities and structure-activity relationships of phenolic compounds. Nat Prod Commun 2010;5(11):1934578X1000501112.

29. Benedec D, Hanganu D, Oniga I, Tiperciuc B, Olah NK, Raita $\mathrm{O}$, et al. Assessment of rosmarinic acid content in six Lamiaceae species extracts and their antioxidant and antimicrobial potential. Pak J Pharm Sci 2015;28(6):2297-303.

30. Singh DP, Verma S, Prabha R. Investigations on antioxidant potential of phenolic acids and flavonoids: the common phytochemical ingredients in plants. J Plant Biochem Physiol 2018;6:219.

31. Zeng L, Zhang G, Lin S, Gong D. Inhibitory mechanism of apigenin on $\alpha$-glucosidase and synergy analysis of flavonoids. J Agric Food Chem 2016;64(37):6939-49.

32. Han L, Fang C, Zhu R, Peng Q, Li D, Wang M. Inhibitory effect of phloretin on $\alpha$-glucosidase: Kinetics, interaction 
mechanism, and molecular docking. Int $\mathrm{J}$ Biol Macromo 2017;95:520-7.

33. Sahnoun M, Trabelsi S, Bejar S. Citrus flavonoids collectively dominate the $\alpha$-amylase and $\alpha$-glucosidase inhibitions. Biologia 2017;72(7):764-73.

34. Wright EM, Sala-Rabanal M, Ghezzi C, Loo DD. Sugar absorption. In: Said H, Editor. Physiology of the gastrointestinal tract. Cambridge: Academic Press 2018;1051-62.

35. Kellett GL, Brot-Laroche E, Mace OJ, Leturque A. Sugar absorption in the intestine: the role of GLUT2. Annu Rev Nutr 2008;28:35-54.

36. Kellett GL, Brot-Laroche E. Apical GLUT2: a major pathway of intestinal sugar absorption. Diabetes 2005;54(10):3056-62.

37. Leturque A, Brot-Laroche E, Le Gall M. GLUT2 mutations, translocation, and receptor function in diet sugar managing. Am J Physiol Endocrinol Metab 2009;296(5):E985-92.

38. Brownlee M. Biochemistry and molecular cell biology of diabetic complications. Nature 2001;414(6865):813-20

39. Vanessa Fiorentino T, Prioletta A, Zuo P, Folli F. Hyperglycemiainduced oxidative stress and its role in diabetes mellitus related cardiovascular diseases. Curr Pharm Des 2013;19(32):5695-703.
40. Samarghandian S, Borji A, Delkhosh MB, Samini F. Safranal treatment improves hyperglycemia, hyperlipidemia and oxidative stress in streptozotocin-induced diabetic rats. J Pharm Pharm Sci 2013;16(2):352-62.

41. Johansen JS, Harris AK, Rychly DJ, Ergul A. Oxidative stress and the use of antioxidants in diabetes: linking basic science to clinical practice. Cardiovasc Diabetol 2005;4(1):5.

42. McCord JM, Fridovich I. Superoxide dismutases: you've come a long way, baby. Antioxid Redox Signal 2014;20(10):1548-9.

43. Poprac P, Jomova K, Simunkova M, Kollar V, Rhodes CJ, Valko M. Targeting free radicals in oxidative stress-related human diseases. Trends Pharmacol Sci 2017;38(7):592-607.

44. Bloch-Damti A, Bashan N. Proposed mechanisms for the induction of insulin resistance by oxidative stress. Antioxid Redox Signal 2005;7(11-12):1553-67.

45. Rains JL, Jain SK. Oxidative stress, insulin signaling, and diabetes. Free Radic Biol Med 2011;50(5):567-75.

46. Wresdiyati T, Sa'diah S, Winarto A. The qntidiabetic properties of Indonesian Swietenia mahagoni in alloxan-induced diabetic rats. Int J Animal Vet Sci 2016;10(10):631-7. 